\title{
PERMAINAN TRADISIONAL PICCEK BAJU DAN PEMBENTUKAN KARAKTER DISIPLIN PADA ANAK USIA MI/SD
}

\author{
Risa Maulida dan Anis Fuadah Z \\ Program Studi Pendidikan Guru Madrasah Ibtidaiyah, UIN Syarif Hidayatullah \\ Jakarta, Indonesia \\ Email : risa.maulida19@mhs.uinjkt.ac.id ${ }^{1}$, anisfuadah.zuhri@.uinjkt.ac.id ${ }^{2}$ \\ Website: \\ https://jurnal.uinantasari.ac.id/index.php/adzka \\ Received: 18 Mei 2020; Accepted: 10 Agustus 2020; Published: 21 Desember 2020 \\ DOI: 10.18952/aladzkapgmi.v10i2.3631
}

\begin{abstract}
Traditional games are one of the cultural heritage that must be preserved, not to be lost or replaced. Piccek Baju is one of the traditional games. Piccek Baju is a traditional game from North Sumatra. This game has many rules. Starting from the number of players, how to play, the preparation before playing to what will be done after playing. The purposes of writing this paper are one (1) introducing the Piccek Baju game from North Sumatra, two (2) recognizing the character of discipline in the 2013 curriculum, three (3) using the traditional Piccek Baju game as a form of disciplinary character development for MI / SD students. . The main focus in this paper is about how the Piccek Baju game can shape a child's personality, especially in terms of discipline. In addition, this paper will describe what are the benefits that will be obtained in the game of clothes pick and the benefits of playing in education. The method used in writing this paper is a library research method or approach. The way data collection is done by studying or exploring from several sources such as journals, books, or other documents from both print and electronic media. The result obtained from this paper is about how traditional games are able to print the character and character of each of the nation's children. Because in a game, cooperation, discipline, cohesiveness, creativity, care, responsibility, even competition can be obtained.
\end{abstract}

Keywords: traditional games of North Sumatra; Piccek Baju; disciplinary character

\begin{abstract}
ABSTRAK
Permainan tradisional merupakan salah satu warisan budaya yang harus dilestarikan keberadaannya, jangan sampai hilang atau tergantikan. Piccek Baju salah-satunya. Piccek Baju merupakan salah satu permainan tradisional dari Sumatera Utara. Permainan ini memiliki aturan yang sangat banyak. Mulai dari jumlah pemain, tata cara bermain, sampai persiapan bermain. Adapun penelitian ini bertujuan untuk mengetahui tentang bagaimana permainan Piccek Baju dapat membentuk kepribadian anak, terutama dalam hal kedisiplinan. Metode yang digunakan dalam penelitian ini adalah metode studi kepustakaan, dimana penulis menelaah atau mengeksplorasi data dari beberapa sumber seperti jurnal, buku, atau dokumen-dokumen lain baik dari media cetak maupun media elektronik yang memiliki kaitan dengan permainan dan karakter disiplin. Hasil penelitian menyatakan bahwa anak pada usia MI / SD cenderung lebih suka bermain dan bergerak. Dalam hal ini, permainan Piccek Baju dapat dijadikan sebagai salah satu alat untuk mengembangkan karakter pada anak, melatih motorik dan menumbuhkan sikap disiplin taat aturan. Karena dalam permainan ini anak harus melakukan gerakan bermain yang baik dan sesuai dengan aturan yang ada.
\end{abstract}

Kata Kunci: permainan tradisional; Piccek Baju; karakter disiplin. 


\section{PENDAHULUAN}

Indonesia merupakan salah satu negara memiliki banyak keragaman baik dari segi bahasa, budaya, adat istiadat, permainan tradisional, pakaian adat, rempah-rempah dan sumber daya yang lainnya. Rasa bangga terhadap Indonesia harus ditanamkan sejak dini. Ada banyak cara yang dapat dilakukan untuk menanamkan rasa bangga sebagai bangsa Indonesia salah satunya dengan mengenal dan melestarikan budaya yang dimiliki bangsa Indonesia sejak zaman dahulu. Bukan hanya bahasa, budaya, dan adat istiadat yang harus dilestarikan, permainan tradisional juga harus dilestarikakn keberadaannya. Euis Kurniati (2016) dalam bukunya menyebutkan bahwa permainan tradisional merupakan suatu aktifitas bermain yang tumbuh dan berkembang di suatu daerah yang memiliki nilai kebudayaan dan diajarkan secara turun-temurun ke setiap generasi. Bermain menjadi salah satu untur penting dalam proses perkembangan anak. Baik berupa perkembangan fisik, emosi mental intelektual, kreativitas maupun sosial. Pada masa usia sekolah permainan yang cenderung diminati adalah permainan yang sifatnya persaingan. (Sanditaria, W. dkk, 2012).

Seiring perkembangan zaman, permainan tradisional mulai ditinggalkan karena adanya permainan yang berbasis elektronik dan visual yaitu game online. (Sanditaria, W. dkk, 2012). Game online merupakan salah satu wujud permainan modern yang banyak digunakan di dunia ini. Burhan dan Tsharir (2005) mengemukakan bahwa game online merupakan permainan komputer yang dapat dimainkan oleh banyak pemain melalui koneksi internet. Game online ada karena semakin berkembangnya ilmu pengetahuan dan teknologi. Perkembangan teknologi menjadi salah satu faktor utama yang menyebabkan anak-anak lebih menyukai game online dari pada permainan tradisional.

Game online berbeda dengan permainan tradisional, dimana dalam permainan game online anak tidak hanya dapat bermain dengan orang yang berada di sebelahnya saja tetapi anak-anak juga dapat bermain dengan beberapa pemain di lokasi yang berbeda. Bermain game dapat berpengaruh positif salah satunya untuk menghilangkan stess atau kemarahan yang sedang dialami para pemain. Di sisi lain, bermain game online juga akan berdampak negatif pada pertumbuhan anak seperti anak akan menghabiskan waktu terpenting dalam hidupnya hanya untuk bermain game, kurangnya sosialisasi dengan orang tua dan teman sebaya karena wak tu yang dimiliki hanya untuk bermain game online, kurang tidur, bahkan rela meninggalkan jam pelajaran hanya untuk bermain game online. (Sanditaria, W. dkk, 2012). Dalam hal ini, peran keluarga sangat penting untuk membentuk karakter seorang anak. Lingkungan keluarga merupakan lingkungan pertama yang anak kenali. Sehingga bimbingan orang tua terhadap anak merupakan pendidikan informal pertama yang didapat oleh anak dalam rangka pembentukan karakter sejak usia dini. (Priyanto \& Widiarti, 2016). Selain lingkungan keluarga, lembaga sekolah juga memiliki peran yang tak kalah penting. Sekolah merupakan lembaga pendidikan formal yang berfungsi untuk mendidik anak-anak dan menjadikannya sebagai masyarakat yang berguna bagi diri sendiri, orangtua, agama, bangsa dan negara. (Sri Hartini, 2017)

Pembentukan karakter tidak lahir begitu saja, ada sebuah proses panjang yang harus ditempuh. Masa pengembangan karakter paling awal dimulai ketika anak masih berusia dini. Pada masa ini disebut dengan periode golden age atau periode keemasan dimana pada usia ini perkembangan anak sangat cepat (Andriani, 2012). Megawangi (2013) menyatakan bahwa anak-anak akan tumbuh menjadi pribadi yang berkarakter apabila lingkungan tempat tinggal anak tersebut merupakan lingkungan yang baik dan berkarakter juga sehingga anak akan tumbuh dan berkembang secara optimal. Berbeda jika lingkungan yang di tempati adalah lingkungan yang tidak baik, tanpa disadari itu akan membuat anak menjadi tidak baik pula. Lingkungan anak bukan hanya lingkungan keluarga saja, tetapi mencangkup semua lingkungan baik lingkungan sekolah, lingkungan bermain ataupun lingkungan komunitas bermain. (Prasanti, 2018). 
Di zaman yang sudah semakin modern ini, pendidikan karakter mulai mengalami penurunan. Hal ini dibuktikan dengan banyaknya tindakan-tindakan atau perilaku ynag menyimpang dari aturan dan moral yang ada. Tindakan menyimpang yang bisa dilakukan oleh pelajar baik tingkat MI/SD, SMP/MTs, Maupun SMA/SMK/MA seperti berbicara kotor, merokok, tidak sopan terhadap guru, tidak menaati aturan di sekolah, merokok, membolos dari pelajaran, berkelahi dan lain sebagainya. Tindakan tersebut sangat memprihatinkan dan sangat keluar dari tatanan kehidupan yang baik dan benar. Maka dari itu, untuk membentuk karakter siswa yang baik maka diperlukan adanya sinergitas antara orang tua dengan guru. Adapun salah satu karakter yang dapat dikembangkan yaitu karakter disiplin. Prilaku disiplin taat aturan harus dibiasakan sejak anak berada pada tingkat MI/SD, karena dengan begitu ketika beranjak dewasa nanti, seorang anak akan terbiasa dengan prilaku hidup berdisiplin. (Sri Hartini, 2017).

Seriati dan Hayati (2014) menyatakan bahwa permainan tradisional dapat membentuk karakter anak seperti belajar bersosialisasi dengan teman, belajar kekompakan, mengendalikan diri, mengendalikan emosi, belajar bertanggung jawab, taat terhadap aturan, bahkan bisa belajar lebih menghormati orang lain. Secara tidak langsung permainan telah membawa misi penanaman karakter sejak dini. Mutiah (2010) juga menyebutkan bahwa permainan dan bermain memiliki banyak fungsi antara lain sebagai sarana menumbuhkan kemampuan bersosialisasi, sarana mengembangkan kemampuan dan potensi anak, mengenali berbagai macam benda, bagaimana sifat dan bentuknya, serta dengan bermain dapat menimbulkan rasa gembira, senang tegang, kecewa sehingga mereka bisa menghayati berbagai rasa yang dirasakan ketika bermain. (Nurul Huda, 2018). Karena bermain merupakan dunia anak, maka permainan dapat dijadikan sebagai salah satu sarana pembelajaran bagi anak khususnya pada anak usia MI/SD yang masih tergolong sangat aktif dalam bergerak. (Irma Novia, 2015).

Salah satu permainan yang dapat membentuk karakter pada anak usia MI/SD terutama dalam hal kedisiplinan adalah permainan tradisional Piccek Baju. Permainan Piccek Baju merupakan salah satu permainan tradisional Indonesia yang berasal dari daerah Sumatera Utara. Permainan ini dikenal dengan sebutan permainan Engklek. Di daerah sunda di Jawa permainan ini disebut dengan permainan Sundhamandha sedangkan di daerah lampung permainan Piccek Baju bernama permainan Ingkling. Permainan ini merupakan permainan perorangan yang dapat melatih keseimbangan, kelincahan, kedisiplinan, dan ketangkasan anak. (Hazriyanti, 2019). Permainan tradisional Piccek Baju dapat dimanfaatkan untuk melatih kedisiplinan karena dalam permainan ini ada banyak aturan yang harus dipatuhi oleh setiap pemain. Dengan begitu anak akan menaati setiap aturan yang ada dalam permainan itu. Sehingga tanpa disadari prilaku berdisiplin dapat tumbuh. Kedisiplinan perlu di terapkan sejak anak usia MI/SD karena sangat penting dalam rangka menumbuhkan moral anak bangsa yang semakin hari semain menurun karena perkembangan zaman. Adapun tujuan penelitian ini yaitu untuk mengetahui tentang bagaimana permainan Piccek Baju dapat membentuk karakter disiplin pada anak usia MI/SD kemudian apa saja manfaat yang akan diperoleh dari bermain.

\section{METODE PENELITIAN}

Metode penelitian yang dilakukan dalam pelitian ini adalah metode studi kepustakaan. Nazir (2013) dalam (Supriyadi, 2016) mengemukakan bahwa studi pustaka merupakan salah satu teknik pengumpulan data dengan melakukan penelaahan terhadap buku-buku, literaturliteratur, laporan-laporan, jurna-jurnal, dan catatan catatan yang berkaitan dengan masalah yang diteliti. Dalam melakukan penelitian, penulis tidak harus terjun langsung ke lapangan untuk mencari sumber data karena sumber tersebut dapat diperoleh dari data-data berdasarkan sumber perpustakaan. Sumber data pada penelitian ini berasal dari jurnal ilmiah, indeks 
skripsi, electronik book, tesis dan sumber lain yang berkaitan dengan masalah yang diteliti. Subjek-objek utama pada penelitian ini yaitu anak-anak tingkat sekolah dasar dan lingkungan bermainnya.

Adapun teknik pengumpulan data yang dilakukan penulis yaitu teknik dokumentasi, dimana penulis mencari data mengenai hal-hal terkait penelitian berupa catatan, buku, makalah, artikel, jurnal dan sebagainya. Dalam teknik dokumentasi, penulis menganalisis dokumen seperti artikel dan jurnal baik dalam segi isi maupun konteks dokumen tersebut sehingga seringkali menggunakan teknik content analysis. (Asfi Manzilati, 2017). "Content analysis is potentially one of the most important techniques in the social sciences. The content analyst views data as representation not of physical events but of the texts images, and expressions that are created to be seen, reed interoreted and acted on for their meanings and must therefore be analysed with such uses in mind." (Klaus Krippendorff, 2004). Melalui analisis ini, peneliti akan melakukan proses memilih, membandingkan menggabungkan dan memilah berbagai pengertian sampai kemudian ditemukan data yang relevan. (Abdi Mirzaqon dan Budi Purwoko, 2017). Alat bantu atau instrumen yang digunakan oleh penulis meliputi buku-buku referensi (seperti kamus, ensiklopedi), indeks buletin dan majalah (seperti jurnal ilmiah), tesis, skripsi serta sumber-sumber lainnya yang berkaitan dengan permasalahan yang diteliti. (Mestika Zed, 2014).

\title{
HASIL PENELITIAN DAN PEMBAHASAN Mengenal Permainan Piccek Baju
}

Piccek Baju adalah salah satu permainan tradisional di Indonesia. Permainan ini memiliki nama yang berbeda disetiap daerahnya. Permainan ini sering disebut dengan permainan Engklek. Ada beberapa pendapat yang mengatakan bahwa permainan engklek memiliki nama Asli "Zondag Maadag". Kata Zondag Maadag berasal dari bahasa belanda. Berdasarkan sejarah, permainan ini masuk ke Indonesia sejak masa penjajahan Belanda. Sebagian pendapat mengatakan bahwa permainan ini berasal dari Inggris. Piccek baju sendiri merupakan sebutan permainan Engklek di daerah Sumatera Utara. Mulyani (2016:111) dalam (Hazriyanti, 2019) menyatakan bahwa permainan Engklek atau Piccek Baju merupakan permainan tradisional melompat atau meloncat pada bidang-bidang datar yang digambar diatas tanah, dengan membuat gambar kotak-kotak kemudian melompat dengan satu kaki dari kotak yang satu kekotak berikutnya. Piccek Baju adalah permainan perorangan yang dilakukan dengan melompat di atas bidang datar yang telah diberi desain seperti baju atau seperti gambar di bawah ini.

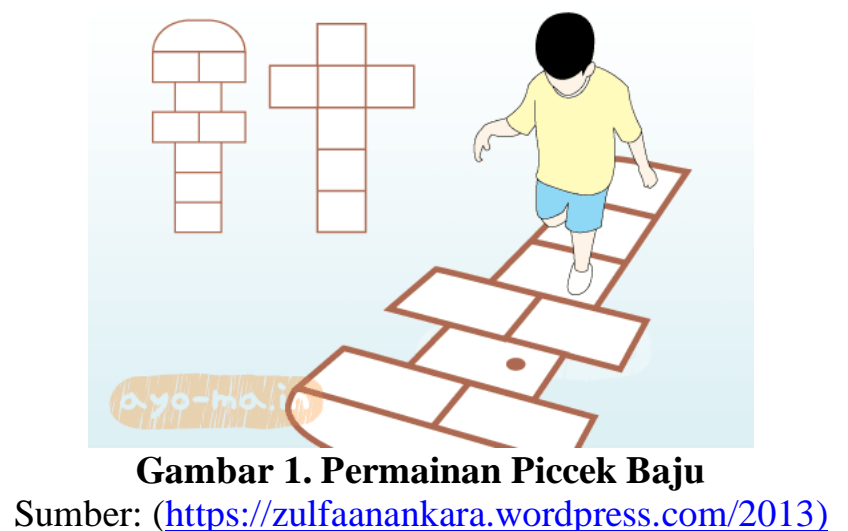

\begin{abstract}
Alat dan Bahan
Permainan Piccek baju disebut juga permainan batu lempar atau gacok. Adapun alat dan bahan yang diperlukan berupa Gacok atau Pion yaitu alat berupa batu, pecahan keramik, pecahan genting, atau koin logam. Gacok atau pion yang terbuat dari pecahan keramik atau
\end{abstract}


genting biasanya berukuran 5-7 cm, berbentuk bukat atau kotak pipih dan tidak tajam. Dan kapur atau kayu kecil, yaitu benda yang dapat dipakai untuk membuat pola Piccek Baju di tanah atau lapangan. (Rizky Yulita, 2017)

\section{Persiapan Permainan}

Sebelum bermain anak-anak biasanya membuat pola berbentuk petak-petak seperti gambar di atas. Petak tersebut akan digunakan sebagai pijakan saat melompat. Dalam permainan ini anak-anak melompat dengan satu kaki. Apabila melanggar anak tersebut harus menghentikan permainannya kemudian dilajutkan dengan pemain berikutnya dan mengulang lagi saat giliran bermainnya tiba. Adapun alat yang dapat digunakan untuk menggambar bisa dengan sebuah kapur atau kayu kecil serta benda yang lainnya yang bisa digoreskan pada tanah untuk membentuk pola. Anak-anak juga memerlukan batu, pecahan kaca atau pecahan genting sebagai pion atau gacon yang akan digunakan sebagai penanda seberapa jauh ia melangkah atau untuk mendeteksi sampai dimana perjalanannya terhenti. Petak yang digambar berjumlah delapan petak (Wiranti et al., 2018).

Anak-anak memulai permainan dengan hompimpa untuk menentukan siapa yang bermain terlebih dahulu dan siapa yang bermain setelahnya. Hompimpa adalah cara menentukan pemenang dengan menggunakan tangan. Hompimpa dilakukan jika pemain terdiri dari tiga orang atau lebih, tetapi jika hanya ada dua orang pemain maka cukup dengan melakukan suit dengan jari tangan. Baik suit dengan menggunakan aba-aba kertas (dengan cara membuka telapak tangan), gunting (menyisakan jari telunjuk dan jari tengah tetap berdiri sedangkan jari lain mengepal) atau batu (jari tangan dikepal semua) dan juga bisa dengan menggunakan jari telunjuk, jempol atau jari kelingking. Melakukan hompimpa biasanya sambil bernyanyi "hompimpa alaium gambreng". Pada saat kata gambreng maka anak-anak menentukan apakah meletakkan punggung tangan atau telapak tangan secara bersamaan. Jika terlihat ada yang berbeda maka dia pemenangnya dan akan memulai permainan diurutan pertama, tetapi jika belum terlihat yang berbeda hompimpa terus dilakukan. Jika tersisa dua orang pemain maka yang dilakukan adalah suit. (Rizky Yulita, (2017).

Suit adalah salah satu cara mengundi untuk dua orang pemain dengan cara mengadu jari untuk menentukan siapa yang menang. Ada dua macam suit yang dikenal di Indonesia yaitu suit jepang (kertas, gunting, batu) dan suit dengan jari telunjuk, jari jempol atau jari kelingking. Untuk menentukan pemenang di antara keduanya yaitu jika jari kelingking bertemu dengan jari jempol maka jari kelingking pemenangnya, apabila bertemu dengan jari telunjuk, maka jari kelingking kalah, dan jika sama-sama bertemu dengan jari kelingking maka suit akan di ulangi kembali. Untuk ibu jari jempol, jika bertemu dengan jari telunjuk maka ia menang. Dan jari telunjuk dikatakan menang jika bertemu dengan jari kelingking. Adapun jika menggunakan suit jepang yaitu cara menentukan pemenangnya yaitu kertas akan menang jika bertemu dengan batu, batu akan menang jika bertemu dengan gunting dan gunting akan menang jika dihadapkan dengan kertas. (Rizky Yulita, 2017). Setelah melakukan hompimpa dan suit, maka telah diketahui urutan bermain. Siapa anak yang bermain pertama sampai siapa anak yang bermain terakhir.

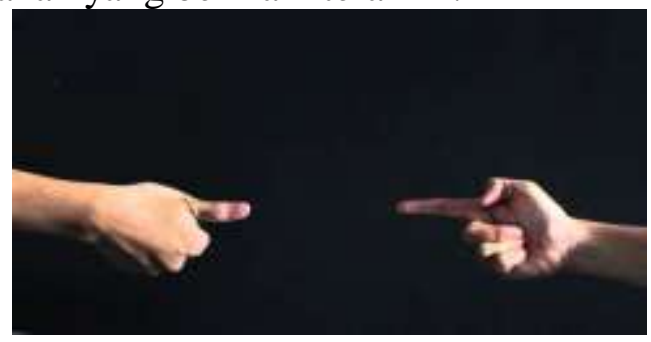

Gambar 2. Suit Indonesia

Sumber: (https://nasional.okezone.com/read/2017/05/13/337/1690080/top-files-mengoreksejarah-suit-tradisi-mengundi-pemenang-dari-negeri-tirai-bambu ) 


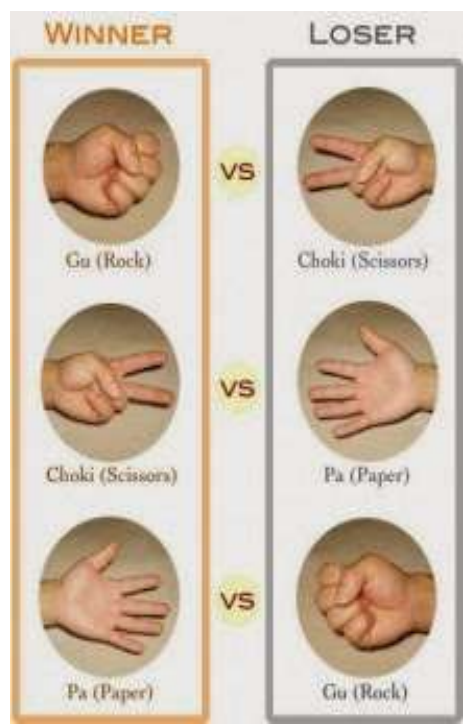

Gambar 3. Suit Jepang

Sumber: (http://animenia-diary.blogspot.com/2014/02/jan-ken-pon-permainan-suit-ala$\underline{\text { nihon.html) }}$

Setelah mengetahui persiapan apa saja yang harus dilakukan sebelum bermain, maka anak-anak pun harus mengetahui aturan ketika bermain piccek baju ini. Adapun aturan dalam permainan Piccek Baju diantaranya yaitu:

1. Permainan dilakukan perseorangan tanpa dibantu oleh teman lainnya.

2. Melempar pion sesuai posisi petak anak itu bermain, pion tidak boleh melewati garis atau pola yang telah di gambar.

3. Permainan dilakukan dengan melompat di setiap petak dengan menggunakan satu kaki, kaki kanan atau kaki kiri itu bergantung pada pemain tersendiri, tergantung kaki mana yang menurutnya kuat untuk melakukan permainan.

4. Petak yang terisi oleh pion atau gacon tidak boleh di injak, dan harus dilewati

5. Saat mengambil pion pun harus menggunakan tangan, tidak boleh melewati garis dan harus tetap mempertahankan posisi berdiri satu kaki atau engklek.

6. Bermain sesuai urutan, tidak boleh mendahului pemain lain.

7. Bermain sesuai petak-petak, mulai dari petak satu sampai petak delapan

8. Jika seorang pemain telah mendapatkan bintang, maka pemain lain tidak boleh menginjak petak yang berbintang kecuali petak itu adalah petak miliknya.

9. Jika petak berbintang terinjak oleh pemain lain, maka pemain tersebut harus berhenti dari permainan dan diganti dengan pemain selanjutnya sampai pada gilirannya bermain lagi. (Mardayani et al., 2016)

Oleh karena permainan piccek baju adalah permainan yang dipenuhi aturan maka diperlukan kedisiplinan anak untuk bisa melakukan permainan dengan baik dan benar. Adapun langkah-langkah permainan Piccek Baju adalah sebagai berikut:

1. Melempar pion pada salah satu petak yang telah digambar, yang bertuliskan angka satu. Pertanda bahwa permainan baru saja dimulai.

2. Pelemparan pion tidak boleh melebihi garis pembatas yang telah dibuat. Jika melebihi, maka pemain dinyatakan gugur dan diganti dengan pemain selanjutnya.

3. Melompat dengan satu kaki pada petak yang tidak diisi oleh pion. Petak yang telah diisi oleh pion tidak boleh dipijak. Para pemain harus melewati petak berisi pion tersebut agar tetap dapat melanjutkan permainan.

4. Lompati setiap petak yang ada, dari petak dua sampai petak delapan dan kembali lagi untuk mengambil pion yang tadi telah dilempar. 
5. Pengambilan pion dilakukan dengan satu tangaan atau dua tangan, tetapi posisi kaki harus selalu dalam keadaan mengangkat.

6. Lakukan hal yang sama pada petak-petak berikutnya

7. Pemain yang menyelesaikan satu putaran penuh terlebih dahulu berhak mendapatkan sawah atau bintang.

8. Untuk mendapatkan sawah atau bintang pemain dapat melempar pion dengan membelakangi gambar piccek baju yang telah dibuat, melempar pion dari atas kepala. Apabila pion tersebut jatuh pada petak pada salah satu petak yanga ada maka ia berhak memiliki petak tersebut.

9. Petak yang sudah dimiliki boleh diinjak dengan dua kaki. Tetapi untuk pemain lain tidak boleh menginjak petak yang sudah dimiliki. Baik menginjak dengan satu kaki atau dua kaki. Apabila menginjak maka pemain tersebut gugur. (Mardayani et al., 2016)

\section{Fungsi atau Manfaat Permainan Piccek Baju}

Fungsi dari permainan Piccek Baju diantaranya yaitu membiasakan diri untuk bersosialisasi dimulai sejak dini, mengembangkan keterampilan sosial anak, meningkatkan perkembangan fisik, koordinasi tubuh, serta mengembangkan keterampilan motorik sdan juga dapat embentuk kepribadian dan emosi anak, melatih kelincahan serta mengajarkan anak untuk disiplin dalam menaati aturan-aturan permainan. Ada beberapa aspek yang dapat dikembangkan dari permainan Piccek Baju yaitu aspek kogniiif, aspek emosional, dan aspek perkembangan fisik. Dalam permainan Piccek Baju, kognitif anak dilatih dari proses berpikir tentang berapa petak yang sudah dilewati dan berapa petak yang belum dilewati dan bagaimana cara untuk melewati setiap petak tanpa melakukan kesalahan. Pada aspek emosional, anak dilatih utuk bisa menerima ketika ia gagal dalam bermain, mengajarkan anak untuk menaati aturan yang ada dalam permainan, serta tidak mendahului kawannya atau sabar dalam menanti giliran bermain. Sedangkan pada aspek perkembangan fisik, anak dilatih dilatih untuk melempar dengan tepat, melompat, menjaga keseimbangan, serta dapat meningkatkan kekuatan otot kaki. (Jamilah, 2017).

Adapun nilai yang bisa diambil dalam permainan Piccek Baju salah satunya yaitu nilai ketangkasan dan juga nilaikedisiplinan. Nilai ketangkasan dapat dilihat dari mulai ia melempar sampai melompat pada setiap petak. Gerakan melompat dengan satu kaki merupakan sarana untuk melatih ketangkasan, kelincahan dan juga keseimbangan tubuh. Adapun nilai kedisiplinan bisa diperoleh pada setiap pemain menaati aturan. Hal kecil yang terlihat sepele, namun bisa mengantarkan anak untuk mulai berdisiplin sejak dini agar ketika dewasa kedisiplinan sudah melekat pada diri individu. (Jamilah, 2017).

\section{Mengenal Anak Usia MI/SD}

Dalam (Sugiyanto, 2005) menyebutkan bahwa anak usia MI/SD merupakan anak berada dalam masa perubahan dan perkembangan secara drastis baik fisik maupun menta. Usia anak MI/SD yaitu berkisar pada 6-12 tahun. Menurut Seifert dan Haffug, perkembangan anak usia MI/SD terdiri dari tiga jenis yaitu perkembangan fisik, perkembangan kognitif dan perkembangan psikososial.

1. Perkembangan Fisik Anak Usia MI/SD

Perkembangan fisik anak usia MI/SD mencangkup pertumbuhan biologis anak yang meliputi pertumbuhan otot, otak dan tulang.

2. Perkembangan Kognitif Anak Usia MI/SD

Menurut Jean Piagget tahap perkembangan kognitif anak terdiri atas:

a. Tahap ensorimotorik terjadi pada usia sekitar 0-2 tahun, pada tahap ini bayi lahir dengan sejumlah refleks bawaan medorong mengeksplorasi dunianya. 
b. Tahap praoperasional terjadi pada usia sekitar 2-7 tahun, pada tahap ini anak belajar menggunakan dan merepresentasikan objek dengan gambaran dan katakata.

c. Tahap operational Kongkrit terjadi sekitar 7-11 tahun, pada tahap ini anak telah mampu menggunakan logika secara memadai.

d. Operasional Formal (sekitar 12-15 tahun), pada tahap ini kemampuan untuk berpikir secara abstrak, menalar secara logis, dan menarik kesimpulan dari informasi yang tersedia

3. Perkembangan Psikososial Anak Usia MI/SD

Perkembangan psikososial yaitu perkembangan pada anak yang berkaitan dengan emosi, motivasi dan perkembangan secara pribadi manusia serta perubahan pola interaksi dengan orang lain.

Pada masa ini, anak usia MI/SD lebih senang bermain, aktif bergerak, dan menyukai bekerja dalam kelompok. Selain itu, anak pada usia MI/SD juga senang merasakan atau melakukan sesuatu secara langsung. (Sugiyanto, 2005).

\section{Mengenal Karakter Disiplin}

Dalam (Aeni, 2014) mengemukakan bahwa pendidikan karakter merupakan sebuah upaya untuk membangun karakter (character building). Elmubarok (2008) menyebutkan bahwa carakter building merupakan proses mengukir atau memahat jiwa dengan sedemikian rupa, sehingga akan berbentuk unik, menarik, dan berbeda dengan orang lain.

Menurut Pusat Bahasa Depdiknas karakter adalah "bawaan, hati, jiwa, kepribadian, budi pekerti, perilaku, personalitas, sifat, tabiat, temperamen, dan watak". Karakter berasal dari bahasa Yunani yaitu kata "Charassian" yang berarti "to mark" atau menandai serta memfokuskan tentang bagaimana mengaplikasikan nilai kebaikan atau keburukan dalam bentuk tindakan atau tingkah laku. Orang yang tidak jujur, kejam, tamak dan perilaku buruk lainnya dikatakan orang berkarakter buruk, sebaliknya orang yang jujur, baik, penyayang, dan berlaku sesuai dengan kaidah moral yang sesuai berarti termasuk orang yang berkarakter baik. Karakter dipengaruhi oleh hereditas (pewarisan watak dari makhluk hidup ke keturunannya), sebagaimana dinyatakan oleh Samani \& Hariyanto (2013) bahwa karakter diartikan sebagai nilai dasar yang membangun pribadi seseorang, dimana pribadi seseorang bisa terbentuk dari pengaruh hereditas maupun pengaruh lingkungan, yang membedakannya dengan orang lain, serta diwujudkan dengan sikap dan perilakunya dalam kehidupan sehari-hari (Aeni, 2014).

Pendidikan memiliki tanggung jawab besar dalam melahirkan warga negara Indonesia yang memiliki karakter kuat sebagai modal dalam membangun peradaban yang tinggi dan juga unggul. Karakter bangsa yang kuat merupakan produk dari pendidikan. Ketika mayoritas karakter masyarakat kuat, positif, tangguh maka peradaban yang tinggi dapat dibangun dengan baik dan sukses. Sebaliknya, jika mayoritas karakter masyarakat negatif, maka karakter negatif dan lemah mengakibatkan peradaban menjadi lemah pula (Sosial et al., 2017).

Adapun nilai karakter yang harus ditampilkaan sesuai karakter yang baik dan kuat yaitu nilai karakter (1) terhadap Tuhan, seperti beriman, bertaqwa, bersyukur, tawakkal, ikhlas, berserah diri dan lainnya. (2) terhadap diri sendiri, seperti adil, jujur, kerja keras, kreatif, semangat, cerdik cermat, bertanggung jawab, disiplin an lainnya. (3) terhadap keluarga, misalnya karakter adil, jujur, berpikir jauh ke depan, kasih sayang, bijaksana, hemat, disiplin, dan juga terbuka. 4) terhadap orang lain, seperti karakter pemaaf, menghargai, rela berkorban, tenggang rasa, ramah-tamah, tertib dan lainnya. 5) terhadap masyarakat dan bangsa, misalnya karakter loyal, ramah tamah, disiplin adil, sopan santun, bersikap hormat. Dan (5) terhadap alam lingkungan seperti cinta lingkungan, mencintai kebersihan, peduli lingkungan. (Hartini, 2017) Adapun salah satu karakter yang harus dikembangkan dalam 
kurikulum pendidikan adalah karakter disiplin karena disiplin merupakan tindakan yang menunjukkan perilaku tertib dan patuh pada berbagai ketentuan dan peraturan. Nilai karakter disiplin sangatlah penting dimiliki oleh manusia untuk memunculkan nilai-nilai karakter baik lainnya. Pentingnya penguatan nilai karakter disiplin di sekolah didasarkan pada alasan bahwa banyak perilaku siswa yang tidak menaati norma disiplin. Banyak yang tidak menaati aturan yang ada di sekolah.

Dalam (Prijodarminto, 1994:23) Disiplin diartikan sebagai suatu kondisi yang tercipta melalui proses dari serangkaian perilaku yang menunjukkan ketaatan, kepatuhan, keteraturan dan, atau ketertiban. Perilaku itu tercipta melalui proses binaan melalui keluarga, pendidikan dan pengalaman yang didapat dari lingkungannya termasuk lingkungan bermain. Menurut E.B Hurlock disiplin berasal dari kata yang sama dengan "disciple", yakni seseorang yang belajar secara suka rela mengikuti seorang pemimpin. Dalam hal ini guru dan orangtua merupakan pemimpin, dimana anak merupakan murid yang belajar dari mereka tentang bagaimana hidup yang berguna, dan berbahagia dengan menaati serta mengikuti aturan yang ada. Jadi dapat dikatakan bahwa disiplin merupakan cara masyarakat mengajar anak berlaku moral yang disetujui oleh suatu kelompok.

Kedisiplinan berkaitan erat dengan kepatuhan dan ketaatan seseorang atau kelompok orang terhadap norma-norma dan peraturan-peraturan yang berlaku, baik yang tertulis maupun yang tidak tertulis. Kedisiplinan dibentuk melalui latihan dan pendidikan sehingga terbentuk kesadaran dan keyakinan dalam dirinya untuk berbuat tanpa paksaan. Seseorang dikatakan sebagai seorang yang disiplin apabila: 1). Taat terhadap peraturan dan menjauhi semua yang dilarang, baik terhadap orangtua, guru, pengurus atau pun teman bermain sekaligus, 2). Peduli terhadap lingkungan dengan mencintai dan selalu menjaga kebersihan, dan 3). Berpartisipasi dalam proses belajar dengan datang tepat pada waktunya, bertanya dan menjawab pertanyaan guru, mengerjakan tugas-tugas dengan tepat waktu, serta tidak membuat suasana gaduh di dalam kelas. Menurut Hurlock tujuan disiplin adalah untuk membentuk perilaku sedemikian rupa hingga agar sesuai dengan peran-peran yang ditetapkan kelompok budaya dan tempat individu itu diidentifikasikan. (Julia, 2014)

\section{Menggunakan Permainan Tradisional Piccek Baju sebagai Bentuk Pengembangan Karakter Disiplin pada Peserta Didik MI/SD}

Bermain adalah hal menyenangkan. Bermain adalah hak bagi setiap anak-anak. Bermain adalah sarana anak-anak dalam mengembangkan segala kemampuannya dalam bergerak dan menguasai lingkunagan serta alam sekitar. Bermain bagi anak usia dini atau bagi anak usia MI/SD dijadikan sebagai sarana untuk mempelajari dan belajar mengenai banyak hal termasuk didalamnya bersosialisasi, menata emosi, toleransi, kerjasama, membiasakan berlaku sportif, peduli, taati peraturan dan lain sebagainya. Bermain bermanfaat bagi kognitif anak, perkembangan motorik anak, perkembangan sosial serta keterampilan bahasa anak. (Noffia, 2015).

Permainan tradisional banyak memberikan pengaruh baik terhadap kognitif, afektif maupun karakter anak MI/SD. Permainan dapat membentuk pribadi dan karakter anak salah satunya seperti permainan tradisional Piccek Baju. Permainan ini merupakan salah satu permainan yang dapat mengembangkan karakter anak dalam hal kedisiplinan. Dimana dalam bermain anak harus selalu berusaha untuk berdisiplin menaati segala aturan mainnya. Juga untuk bersabar dan tekun dalam melewati petak demi petak agar mendapatkan puncak dalam bermain. Tak hanya berdisiplin, permainan piccek baju juga dapat mengembangkan motorik anak. Karena dalam permainan ini anak-anak dituntut untuk banyak melakukan aksi bukan pemikiran. Melompat dengan satu kaki, mengambil pion dengan satu tangan, melewati sawah atau bintang yang dimiliki teman sepermainannya serta melewati petak demi petak tanpa menginjak batas garis adalah hal yang sangat memerlukan kedisiplinan, ketekunan, kesabaran 
dan keterampilan motorik anak dalam bergerak. (Jamilah, 2017).

Diharapkan dengan adanya permainan Piccek Baju ini, anak-anak usia MI/SD dapat menerapkannya dalam dunia sekolah. Disiplin dalam menaati aturan, disiplin dalam mengerjakan semua tugas yang diberikan oleh guru sampai pada disiplin dan bertanggung jawab terhadap tugas yang diembannya seperti tugas piket kelas, tugas menghapus, tugas membersihkan wc dan lain lain. Andrie Wongso mengatakan bahwa disiplin adalah senjata ampuh yang harus dimiliki setiap orang yang mau sukses! Dan untuk memiliki disiplin itu harus dibiasakan, tak jarang pula harus dipaksakan. Karena salah satu kunci sukses adalah disiplin maka disiplin harus dibiasakan sejak anak-anak.

\section{PENUTUP}

Dari uraian diatas dapat diketahui bahwa pendidikan memiliki tanggung jawab besar dalam melahirkan warga negara Indonesia yang memiliki karakter bermutu sebagai modal dalam membangun peradaban yang tinggi dan juga unggul. Bermain juga merupakan sarana anak-anak untuk mengembangkan segala kemampuannya dalam bergerak dan menguasai lingkungan serta alam sekitar. Salah satu permainan yang memberi pembelajaran adalah permainan tradisional. Permainan tradisional mengandung nilai-nilai pendidikan dan nilai budaya, serta dapat membentuk karakter anak MI/SD.

Permainann Piccek Baju merupakan salah satu permainan tradisional Indonesia yang berasal dari daerah Sumatera Utara. Fungsi dari permainan Piccek Baju yaitu membiasakan diri untuk bersosialisasi dimulai sejak dini, mengembangkan keterampilan sosial anak, meningkatkan perkembangan fisik, koordinasi tubuh, dan mengembangkan keterampilan motorik, membentuk kepribadian dan emosi anak, melatih kelincahan, serta mengajarkan anak untuk disiplin dalam menaati aturan-aturan permainan. Permainan Piccek baju dapat membentuk karakter anak pada usia MI/SD dalam disiplin taat aturan. Karakter disiplin sangat diperlukan bagi setiap manusia untuk mencapai kesuksesan maka dari itu penanaman karakter disiplin harus ditanamkan sejak dini.

\section{DAFTAR PUSTAKA}

Aeni, A. N. (2014). Pendidikan Karakter Untuk Siswa SD dalam Perspektif Islam. Mimbar Sekolah Dasar, 1(1), 50-53.

Affandi, M. (2013). Pengaruh Game Onine terhadap Tingkat Efektivitas Komunikasi Interpersonal pada Kalangan Pelajar Kelas 5 SDN 009 Samarinda. e-Journal Ilmu Komunikasi, 1(4), 178.

Andriani, T. (2012). Permainan Tradisional Dalam Membentuk Karakter Anak Usia Dini. In Jurnal Sosial Budaya, 9(1), 122-130.

Hartini, S. (2017). Pendidikan Karakter Disiplin Siswa di Era Modern Sinergi Orang Tua dan Guru di Mts Negeri Kabupaten Klaten. Journal Basic Of Education, 2(1), 38-40.

Hazriyanti, \& Nasriah. (2019). Pengaruh Permainan Engklek terhadap Perkembangan Sosial Anak Usia 5-6 Tahun di TK Perwanis Medan. Jurnal Usia Dini, 5(2), 20-24.

Jamilah, R. J. (2017). Peran Permainan Tradisional Engklek dalam Meningkatkan Motorik Kasar Anak Usia 5-6 Tahun di RA Al-Mukhlisin, 7-23.

Julia, Z. S. (2014). Teori Kedisiplinan. 11-35

Kurniati, E. (2016). Permainan Tradisional dan Perannya Dalam Mengembangkan Keterampilan Sosial Anak. Jakarta: Prenada Media Group.

Krippendorff, K. (2004). Content Analysis: An Introduction To Its Methodology. London: Sage Publication.

Manzilati, A. (2017). Metodologi Penelitian: Paradigma. Metode dan Aplikasi. Malang: UB Media.

Mardayani,K. T., Putri Mahadewi, L. P., \& Magta, M. (2016). Penerapan Permainan 
Tradisional Engklek untuk Meningkatkan Kemampuan Motorik Kasar Kelompok B di Paud Widhya Laksmi, e-Journal Pendidikan Anak Usia Dini Universitas Pendidikan Ganesha Jurusan Pendidikan Guru Pendidikan Anak Usia Dini, 4(2), 2-5.

Marlina, M. E. (2013). Kurikulum 2013 yang Berkarakter. In JUPIIS, 5(2), 28-36.

Mirzaqon, A. \& Purwoko, B. (2017). Studi Kepustakaan Mengenai Landasan Teori dan Praktik Konseling Expressive Writing. Jurnal BK UNESA, 8(1). https://media.neliti.com/media/publications/253525-studi-kepustakaan-mengenai-landasanteor-c084d5fa.pdf diakses pada 11 Juni 2020.

Noffia, I., \& Margaretha. (2015). Mengembangkan Disiplin Anak Usia Dini melalui Permainan Tradisional. Cakrawala Dini, 5(2), 112-113..

Prasanti, D., \& Fitriani, D. R. (2018). Pembentukan Karakter Anak Usia Dini: Keluarga, Sekolah, Dan Komunitas?. Jurnal Obsesi, 2(1), 14-15.

Priyanto, A., Widiarti, P. W., \& Endarwati, L. (2016). Upaya Orang Tua dalam Pembentukan Karakter Kebangsaan Anak Usia Dini Melalui Cara Memilih Produk. Jurnal Civics, $13(1), 1-2$.

Rusdiana. (2018). Implementasi Strategi Bermain Peran untuk Meningkatkan Hasil Belajar Siswa Kelas 2 MIN 9 Banjar. Al-Adzka: Jurnal Ilmiah Pendidikan Guru Madrasah Ibtidaiyah, 8(2), 125.

Sanditaria, W. (2012) Adiksi Bermain Game Online pada Anak Usia Sekolah i Warung Internet Penyedia Game Online Jatinangor Sumedang.

Sugiyanto. (2005). Karakteristik Siswa SD. 1-6.

http://staffnew.uny.ac.id/upload/132319838/pengabdian/Karakteristik+Siswa+SD.pdf diakses pada 11 Juni 2020

Suit Jari Khas Anak Indonesia https://nasional.okezone.com/read/2017/05/13/337/1690080/top-files-mengorek-sejarahsuit-tradisi-mengundi-pemenang-dari-negeri-tirai-bambu diakses pada 30 Mei 2020

Suit Jepang http://animenia-diary.blogspot.com/2014/02/jan-ken-pon-permainan-suit-alanihon.html) diakses pada 30 Mei 2020

Supriyadi. (2016). Community Of Practitioners : Solusi Alternatif Berbagi Pengetahuan Antar Pustakawan. Lentera Pustaka, 2(2), 84-85.

Surahman, E., \& Mukninan. (2017). Peran Guru Ips sebagai Pendidik dan Pengajar dalam Meningkatkan Sikap Sosial dan Tanggung Jawab Sosial Siswa SMP. Harmoni Sosial: Jurnal Pendidikan IPS, 4(1), 2-5.

Wafiq, N. H. (2018). Pembentukan Karakter pada Siswa Sek olah Dasar melalui Permainan Tradisional. Prosiding Seminar Nasional: Penguatan Pendidikan Karakter pada Siswa Dalam Menghadapi Tantangan Global, 244-246

Wiranti, D. A., \& Mawarti, D. A. (2018). Keefektiffan Permainan Engklek dalam Mengembangkan Kemampuan Motorik Kasar Anak Usia Dini. Refleksi Edukatika : Jurnal Ilmiah Kependidikan, 9(1), 67-69.

Yulita, R. (2017). Permainan Tradisional Anak Nusantara. Jakarta: Badan Pengembangan dan Pembinaan Bahasa.

Zed, M. (2008). Metode Penelitian Kepustakaan. Jakarta: Yayasan Obor Indonesia.

Zulfaanankara. Permainan Tradisional dari Sumatera Utara. https://zulfaanankara.wordpress.com/2013) diakses pada 06 April 2020. 